\title{
A Cross-National Measure of Electoral Competitiveness*
}

\author{
Mark Andreas Kayser ${ }^{\dagger}$ \\ René Lindstädt $\ddagger$
}

5 January 2015

\begin{abstract}
Electoral competitiveness is a key explanatory construct across a broad swath of phenomena, finding application in diverse areas related to political incentives and behavior. Despite its frequent theoretical use, no valid measure of electoral competitiveness exists that applies across different electoral and party systems. We argue that one particular type of electoral competitiveness - electoral risk - can be estimated across institutional contexts and matters most for incumbent behavior. We propose, estimate and make available a cross-nationally applicable measure for elections in 22 developed democracies between 1960 and 2011. Unlike extant alternatives, our measure captures vote volatility and is constructed at the party (not system) level, exogenous to most policy predictors, and congruent with the perceptions and incentives of policy-makers.
\end{abstract}

*Authors' note: We gratefully acknowledge comments and suggestions from Francisco Cantu, Harold Clarke, John Curtis, David Fortunato, Jeff Gill, Bernard Grofman, Jude Hays, Simon Hix, Ellen Immergut, Drew Linzer, Michael McDonald, Shaun McGirr, Matthias Orlowski, Thomas Plümper, Ronald Rogowski, Tal Sadeh, Peter Selb, Jon Slapin, Stuart Soroka, Piero Stanig, Daniel Stegmüller, Randy Stevenson, Jack Vowles, and Robert Walker. Versions of this paper were presented at the annual meeting of the European Political Science Association and at the University of Essex, the University of Exeter, the Hertie School of Governance, the London School of Economics, the University of Oxford, and the University of Zurich. We thank Tanya Bagashka, Aaron Gallant, Patrick Lam, and Kong Joo Shin for the original data collection in 2006 and Johannes Kleibl, Arndt Leininger, Grzegorz Wolszczak, and Mathew Wong for more recent research assistance. Eric Chang, Miriam Golden, Bing Powell, Lawrence Ezrow and Margit Tavits have kindly provided us with replication data that we have used for validity checks in various domains.

${ }^{\dagger}$ Hertie School of Governance, Berlin, kayser@hertie-school.org

$\ddagger$ University of Essex, rlind@essex.ac.uk 
Electoral competitiveness is simultaneously one of the most central and mismeasured constructs in the study of democratic politics. In a recent five-year period, approximately one in every second issue of the American Political Science Review, American Journal of Political Science and Journal of Politics published an article related to electoral competitiveness. ${ }^{1}$ Equally as notable, due to the absence of a conceptually coherent and cross-nationally valid measure, a large majority of them (21 of 29) were single-country studies while the remainder either employed a measure of a related but different concept from electoral competitiveness (such as democracy or institutional proxies), an invalid measure, or did not include a measure at all.

Lacking a cross-nationally valid measure of electoral competitiveness, scholars have resorted to conceptually and empirically imprecise devices such as typologies (Sartori, 1976), idiosyncratic single-country measures (Ranney, 1976), institutional proxies (Hobolt and Klemmensen, 2008; Schleiter and Voznaya, 2012), or ordinal categorizations such as the Executive Index of Political Competitiveness (Beck et al., 2001). Alternatively, scholars can employ broader measures of democracy that may correlate with electoral competitiveness (e.g., Pemstein, Meserve and Melton, 2010; Gugiu and Centellas, 2013) or sets of covariates, each of which capture some component of competitiveness (e.g., Immergut and Abou-Chadi, 2014). Many of these measures are at the system-level of analysis and static. None are capable of capturing small changes in competitiveness in a single measure for a ruling party. ${ }^{2}$

The failure to develop a generalizable measure of electoral competitiveness poses not only a challenge for model identification but a challenge for understanding the consequences of different forms of democratic governance. Politicians elected in competitive settings purportedly respond more to their median constituents (Ansolabehere, Snyder and Stewart,

\footnotetext{
${ }^{1}$ See the table in the Supporting Materials.

${ }^{2}$ A notable exception to these rough measures are the more recent and focused competitiveness measures estimated by Grofman and Selb (2009) and Blais and Lago (2009). Whereas the other alternatives are too broad, however, the Grofman-Selb measure may be too narrow for general applications, as it is specifically designed for turnout models. The Blais-Lago measure is at the district, not national, level.
} 
2001; Powell, 2000), moderate their partisan preferences in fiscal policy (Solé-Ollé, 2006), and provide better, more and more timely public goods (Adserà, Boix and Payne, 2003; Hecock, 2006). Voters, for their part, purportedly hold representatives more accountable (Canes-Wrone, Brady and Cogan, 2002), turn out to vote in greater numbers (Powell, 1986; Selb, 2009) and weigh both incumbent performance (Koch, 1998) and issues (Lachat, 2011) more when elections are competitive. In combination with other innovations in political measurement, theoretically important relationships can also be tested for the first time cross-nationally. Are more compact party systems (Alvarez and Nagler, 2004) more electorally competitive? Does greater transparency (Hollyer, Rosendorff and Vreeland, 2014) make incumbents less secure? A valid cross-national measure of electoral competitiveness should not only operationalize a central political concept but help to gauge its effects in numerous policy domains across multiple institutional and political contexts.

\section{Electoral Competitiveness}

\subsection{Conceptual Definition}

Ideally, a useful cross-national measure of electoral competitiveness should provide, above all, (a) conceptual clarity but also (b) a unit of analysis matching the actors, i.e., no system- or country-level measure, (c) consideration for electoral volatility (not just, say, vote margins), (d) a direct connection to the loss of power, (e) an interval-level scale and, in order to support policy analysis, (f) congruence with the executive's perspective on his or her political security.

We begin by proposing a conceptually clear and ultimately operationalizable definition of one type of electoral competitiveness, electoral risk, that meets the above criteria. We define electoral risk as the expected probability that the plurality party in parliament loses its seats plurality in the next election. ${ }^{3}$ Thus we capture a conceptually simple

\footnotetext{
${ }^{3}$ Other scholars have arrived at similar definitions for an ideal measure of electoral competitiveness (Boyne, 1998) but we, to the best of our knowledge, are the first to estimate it as a single variable.
} 
construct of great importance to the dominant policy-maker, regardless of context, that is forward-looking and likely to influence behavior. At lower and higher loss probabilities (LPRs) plurality parties should be less responsive to the electorate since modest changes in vote share are unlikely to cost or win them a seats plurality, respectively.

Why focus on the plurality party? As the largest party in parliament is almost always entitled to the first attempt at forming a government, prime ministers are usually from the largest party. In our OECD sample (see below), prime ministers are from the largest party in $82 \%$ of the elections, and this figure rises considerably further when only the first governments formed after an election are considered. ${ }^{4,5}$ Retaining this post matters in all electoral and party systems because it entails agenda setting powers. The consequences of losing plurality status do differ across systems. In two-party systems, losing plurality status in parliament almost inevitably means leaving government while in multi-party systems with coalition governments, this is not necessarily the case. Nevertheless, in both systems, losing a seats plurality and the prime-ministership is an eventuality that large parties do their utmost to avoid. ${ }^{6}$ Minority governments do not differ in this incentive either: a party that loses the legislative plurality can expect to lose the prime minister's office. Thus, leaders in single-party majority, coalition and minority governments all have a strong incentive to retain their seats plurality. We can expect that leading parties in an electorally competitive setting, regardless of government type, may behave differently in office than those in a noncompetitive system.

\footnotetext{
${ }^{4}$ Technocratic governments are an obvious exception.

${ }^{5}$ We also estimate loss probabilities for a presidential system and a few semi-presidential systems. The incentive to retain a plurality in the lower house of the legislature may weaken but it nevertheless remains.

${ }^{6}$ We choose to emphasize seats plurality rather than majority as some scholars have advocated (see, for example, Elkins (1974)) because we are looking to capture the objective of individual parties that translates across systems. A majority is often not realistically attainable for a single party in a multiparty system. Plurality status provides important, albeit different, benefits to a party in both systems. Indeed, one early effort at conceptualizing inter-party competition defined success with a varying 'magic number' of votes that would confer largest party status across autocracies and various forms of democracies (Przeworski and Sprague, 1971).
} 
Electoral risk, as we define it, is a function of two elements: the expected variability in national-level party vote share; and the manner in which changes in a party's vote share produce changes in its legislative seat share. The first depends on political and economic events; politicians, we argue, predict the probability of given vote swings in the upcoming election by observing the volatility of voters' electoral support for plurality parties in past elections. The second component, the seats-votes elasticity, depends upon a country's electoral rules and the particular geographic distribution of each party's voters. Parties whose electoral support is based on districts won by large margins, for example, will enjoy a lower seats-votes elasticity, as a given swing in the vote will not translate into as large a swing in seats (Chen and Rodden, 2013). Together these factors determine the expected probability of an election outcome, as seen from the perspective of newly elected leaders contemplating the security of their position against future electoral swings. Because we estimate our loss probabilities from the perspective of the first day after an election, our measure, in contrast to many political variables, enjoys exogeneity from many potential policy-related dependent variables.

No measure is without limitations and we note ours up front. We seek to replicate the calculations of a the head of a plurality party, i.e., the likely prime minister, immediately following an election. For actors to believe past election swings to be predictive of future swings, we must assume a reasonably stable party system. For this reason, we limit our measure to developed democracies.

\section{Data and Operationalization}

The focus of this article on one type of electoral competitiveness, electoral risk, compels us to restrict our sample to countries with consolidated party systems. Democracies with party systems in which major parties do not continue to exist over consecutive elections are difficult to analyze. To this list of excluded states, we also add those in which the possibility of election-based executive replacement is ruled out. For example, rotating executive powers 
between parties preclude the use of Switzerland. The country sample that we employ here consists of the standard set of developed countries — the 24 members of the OECD in 1990, minus Turkey and Switzerland - but we note that the potential sample of countries for our measure is much larger. ${ }^{7}$

Our calculation of loss probabilities, as we discuss below, depends on (a) seats-votes elasticities and (b) past vote swings. Newly elected leaders, we argue, look at both the district-by-district competitiveness of elections that influence how large a seat swing could result from a small swing in vote share as well as at past swings in vote share to develop a sense of electoral security. Seats-votes elasticities depend on patterns of contestation between multiple parties across electoral districts and, hence, require district-level data in SMD countries. In PR countries, we treat the whole country as a single district. ${ }^{8}$ We have been able to collect district-level data back to 1945 for most SMD countries.

We also need data on a number of historical elections before we can calculate loss probabilities for a given election year. As we discuss below, we calculate the loss probabilities from past vote-share swings by way of kernel density estimation. Of course, the accuracy with which we can calculate the loss probabilities depends on the number of data points. We use only the six previous elections for the density estimation both because this maximizes our sample size and because elections even further in the past are less likely to remain in political memory. Consequently, the first six elections after a transition to a new electoral system, as was the case in Italy (1994), Japan (1996), and New Zealand (1996) must be omitted. France did hold one election under proportional rules in 1986. In this case, we simply assume that politicians in the restored majoritarian system overlooked this election to infer vote volatility. Fortunately, electoral system changes are rare.

\footnotetext{
${ }^{7}$ We provide detailed information on our data and sources in our online appendix.

${ }^{8}$ Note, however, that some research has shown interesting districting effects under PR. See, for example, Monroe and Rose (2002).
} 


\subsection{Loss Probabilities}

The first step toward estimating the perceived loss probability of new prime ministers is to calculate the party-specific seats-votes elasticities. Based on the geographic distribution of party support across electoral districts and patterns of party contention, how great an increase (decrease) in seat share would result from a uniform one-percent increase (decrease) in vote share? We build on an innovative new method of calculating such elasticities by Linzer $(2012 a) .{ }^{9}$ Linzer employs finite mixture distributions fitted to district-level election returns. This produces a very close approximation of the underlying distribution of party electoral support across districts. His method then repeatedly samples from this multimodal distribution to produce a large series of hypothetical election outcomes. When taken together, the results of this simulation produce an estimate of the number of legislative seats each party should expect to win for plausible shifts in their national-level vote share. The slope of this seats-votes relationship reveals the relative concentration or dispersion of a party's vote support in the populace, and thus its insulation from or vulnerability to future swings in the vote share. For a hypothetical one-percent change in their national vote share, parties with a high concentration of voters in districts will tend to gain (or lose) few seats, while parties with voters spread more evenly over districts will tend to gain (or lose) many seats. Stated slightly differently, the smaller the shift in national vote share needed to gain one additional seat, the greater a party's geopolitical advantage. For France, where parties compete independently in the first round but form alliances for the second round, we use second-round party groupings instead of parties as our unit of analysis as detailed in the online appendix.

We estimate seats-votes elasticities only for parties in SMD systems, assuming that seatsvotes elasticities are equal to one for all parties in PR systems (see also Linzer, 2012a, fn. 1, p. 401). Orlowski (2014) has empirically confirmed this assumption for multiple parties in

\footnotetext{
${ }^{9}$ Thankfully, he has made this procedure available in an $\mathrm{R}$ library (Linzer, 2012b) called seatsvotes (Linzer, 2012c).
} 
each of nine PR democracies with Linzer's method. We additionally illustrate this regularity by estimating seats-votes elasticities near unity for a limiting case, Spain, and a more typical case, Austria. Spain, which hosts a proportional electoral system with relatively low district magnitudes, many regional parties and overrepresentation of large parties has been described as "proportional representation with majoritarian outcomes" (Hopkin, 2008). ${ }^{10}$ It is one of the most likely PR states to deviate from a S-V elasticity of one. Austria employs a high threshold ( $4 \%$ of the national vote) for a party to enter parliament but its effects are largely offset by second-tier compensatory mechanisms. As we show in our online appendix, Linzer's method estimates an S-V elasticity of nearly one for the major parties in both countries.

Once seats-votes elasticities have been estimated from district-level data, we turn to the question of loss probabilities. From a new incumbent's perspective, the best estimate of the seats-votes relationship in the next election is the observed relationship between seats and votes from the most recent election. Given this measure of geopolitical support for the incumbent's party and that of competitors, what is the probability of a vote swing occurring that is sufficiently large to displace the leader's party as the largest in parliament? ${ }^{11}$ For this to happen, the seat share of a party that is not presently the largest would have to exceed that of the presently largest party. Calculating this probability thus requires a distribution of the joint seat swings of both the largest and second-largest party. ${ }^{12}$ The probability of the largest party being displaced at time $t+1$ is the probability of the swing in the seat share gap between the two largest parties exceeding the seat share gap at time $t$ in which the seat swing, $s_{t}$, is calculated as follows.

$$
s_{t}=\Delta v_{1, t} \tau_{1}^{*}-\Delta v_{2, t} \tau_{2}^{*},
$$

\footnotetext{
${ }^{10}$ a.k.a., the "electoral sweet spot" (Carey and Hix, 2011).

${ }^{11}$ Note that we assume that the prime minister comes from the largest party.

${ }^{12}$ Calculating the probabilities that the third, fourth and even smaller parties become the plurality party in the next election is possible but unnecessary. When a new party gained a plurality in our sample, it was the second largest party 97.4 percent of the time.
} 
where $\Delta v_{i, t}, i \in\{1,2\}$, represents the aggregate-level party vote share differential between time $t+1$ and $t$. In particular, $\Delta v_{i, t}=v_{i, t+1}-v_{i, t}$. The $\tau_{i}^{*}$ are the estimated seats-votes elasticities from the most recent election and are therefore not indexed by time. Substantively, by not indexing the seats-votes elasticities, we assume that a new incumbent assumes that the geographic distribution of support remains as it is presently when looking back in time to estimate the probability of removal in the next election. By subtracting $\Delta v_{2, t} \tau_{2}^{*}$ from $\Delta v_{1, t} \tau_{1}^{*}, s_{t}$ is defined as the seat swing against the incumbent.

Of course, incumbents at time $t$ cannot know their party's vote share or that of the second-largest party at time $t+1$, so they have to rely on a proxy measure. We assume that incumbents draw on the experience of previous plurality parties to assess vote volatility. ${ }^{13}$ More concretely, after an election, on the first day of a new government (assuming that it forms soon after an election), the leader of the largest party in parliament assesses the probability of the party losing its plurality with a hypothetical question: Given the current distribution of geographical support for parties across districts and the vote volatility in recent elections, what is the probability of an electoral swing costing my party its parliamentary plurality?

We calculate $s_{t}$ for all available election years in our data set and use the distribution of joint seat swings from time 1 to $t-1$ to approximate the probability of a large enough seat swing to displace the current plurality party at the next election at time $t+1 .^{14}$ For that purpose, we need a function that maps the sequence of historical seat swings to a probability density, which we can then integrate to calculate the likelihood of a sufficient seat swing to displace the plurality party. More formally, we need:

$$
g:\left\{s_{n}\right\}_{1}^{t-1} \rightarrow f(s)
$$

\footnotetext{
${ }^{13}$ Some authors (e.g., Bartolini and Mair, 1990; Tavits, 2005) have associated electoral volatility with electoral systems. Recent work by Bischoff (2013) dispells concerns that electoral systems might have a direct effect on volatility.

${ }^{14}$ Vote shares from $t$, the election in question, are included in $t-1$ because it measures change.
} 
Given the small number of elections we can draw on to derive $f(s), g$ needs to be a function that smoothes the distribution, which is why we use a kernel density function for $g$, such that

$$
g(x)=\frac{1}{n h} \sum_{i=1}^{n} K\left(\frac{x-x_{i}}{h}\right)
$$

where $h>0$ is the bandwidth, and $K$ is the kernel function, which we assume to be Gaussian, such that

$$
K(u)=\frac{1}{\sqrt{2 \pi}} e^{-\frac{1}{2} u^{2}}
$$

This kernel density represents an estimate of seat swing probabilities between the two largest parties, as informed by historic vote swings and the current geographic distribution of party support. We then use the density to calculate the probability of the largest party losing its plurality (loss probability or LPR). More specifically, we calculate the area under the kernel density up to the critical value in the domain that is equal to or greater than the seat share gap between the two largest parties. Thus, the new incumbent's expected loss probability is

$$
L P R=\int_{-\infty}^{-d} g(x) d x
$$

where $d=\left(t s_{1}-t s_{2}\right) / \sum_{i=1}^{n} t s_{i}$ is the difference (from the perspective of party 1 ) between party 1 's total seats $\left(t s_{1}\right)$ and party 2 's total seats $\left(t s_{2}\right)$ divided by the total number of seats in parliament $\left(\sum_{i=1}^{n} t s_{i}\right)$.

In the online appendix, we provide a figure, which shows the distributions of loss probabilities for the case of Austria for different specifications of the kernel function (Gaussian, Epanechnikov, rectangular, triangular, biweight and cosine) as well as different bandwidth specifications [Silverman's (1986) rule of thumb and Sheather and Jones's (1991) pilot estimation of derivates]. The differences in LPR distributions across different specifications are 
negligible.

[Table 1 about here.]

[Figure 1 about here.]

Table 1 presents the mean and standard deviations of the plurality party loss probabilities for elections between the seventh election after 1945 (1960 for the US House, approximately 1970 for many others) and 2011. As the box plots in Figure 1 also show, loss probabilities exhibit considerable variation between and within countries. On average, single-member district systems display higher loss probabilities than proportional systems. Extremely high and low LPRs suggest lower levels of electoral competitiveness. An LPR of .5, approximately the median for pre-1996 New Zealand, is the most competitive.

\section{Validity}

Validity testing for a variable designed to measure the electoral vulnerability of the largest party in the legislature as perceived right after an election is not straight-forward. An advantage of a measure built from past vote swings and the seats-votes relationship from the recently concluded election is that it is likely exogenous to political and economic developments that occur within a term. A drawback is that the many events in the years between our LPR measure and the next election make outcomes in the next election a poor benchmark for construct validity. The best validity measure is likely the association with governance outcomes since they follow from the executive party's perception of electoral vulnerability and are more temporally proximate to the time of measurement. We use cross-national price levels as such a governance outcome. 


\subsection{Price Levels}

Work by Rogowski and Kayser (2002) has suggested that countries with majoritarian electoral systems, ceteris paribus, enjoy real price levels approximately ten percent lower than in their proportional counterparts. The mechanism that they espouse but do not directly test is electoral competitiveness (see Chang, Kayser and Rogowski (2008); Chang et al. (2011)). Greater electoral competitiveness in SMD systems incentivize politicians to tilt regulation in favor of consumers rather than producers, thereby lowering prices.

We test the effect of our measure of electoral risk (LPR) on real price levels in Table 2 but we also take the opportunity to examine what we believe to be the two most common alternative measures used in the literature, vote margins and seat margins. Vote and seat margins report the difference between the top two parties in their vote and seat shares, respectively. Although they are indeed informative of a the largest party's electoral vulnerability, neither margin measure performs well cross-nationally because of a failure to account for volatility. What constitutes a safe margin in the Netherlands where volatility in vote (and seat) shares is generally low would promise little electoral security in Canada where volatility is high. Volatility also poses a challenge for margins as a measure of electoral security when it changes over time with a country. Indeed, one of the most famous debates in American politics, over implications of the "vanishing marginals" in the US Congress (Mayhew, 1974), was shown to be essentially a measurement problem when Mann (1978) and Jacobson (1987) demonstrated that larger vote margins did not translate into safer seats because vote volatility had increased. Indeed, scholars have noted the importance of vote volatility to measuring electoral competitiveness even before Mayhew (Przeworski and Sprague, 1971) and, more recently and empirically, in contexts outside of the US (Bodet, 2013).

[Table 2 about here.]

We test the cross-national validity of loss probability, vote margins and seat margins by regressing real price levels on them in a pooled panel dataset that covers 22 OECD 
countries, 1970 to 2010. ${ }^{15}$ Like the Chang, Kayser and Rogowski (2008), we include the relevant controls identified in the "Law of One Price" literature. Electoral competitiveness should be greatest at middling values of loss probability. An incumbent party sure to win or sure to lose need not cater to the interests of votes as closely. We add the square of $L P R$ to capture this non-linearity. We assume that the values for LPR for non-election years are the same as the value for the most recent election and, because we are interested in cross-national effects, we omit country fixed effects.

Neither vote nor seat margins exhibit a statistically significant relationship with real prices in Table 2. Loss probability (LPR), in contrast, demonstrates a substantively and statistically significant effect. Figure 2, based on Model 1, plots out predicted real price levels over different loss probabilities, holding all of the variables other than LPR and its square at their means. Results conform to theoretical expectations. Prices are lowest where elections are most competitive $(L P R \approx .5)$ suggesting that politicians to tilt regulatory policy in favor of consumers where electoral competition is greatest.

[Figure 2 about here.]

\subsection{Plurality party change}

As mentioned above, our loss probability (LPR) measure is primarily designed to match the perceived electoral risk of the plurality party in the legislature, most often the prime minister's party, immediately following an election. The absence of alternative measures of this concept make construct validity difficult. Our primary claim to measurement validity rest, first and foremost, on the theoretical match of our method to the information that the plurality party leader would have and value. The next best validity test is the ability of our loss probability to explain outcomes that have been linked to electoral competitiveness in the existing literature (as shown above in Section 3.1). Nevertheless, a measure of perceived

\footnotetext{
${ }^{15}$ Australia, Austria, Belgium, Canada, Denmark, Finland, France, Germany, Greece, Iceland, Ireland, Italy, Japan, Luxembourg, Netherlands, New Zealand, Norway, Portugal, Spain, Sweden, the United Kingdom and the United States.
} 
electoral risk should be at least weakly related to election outcomes, even though they occur several years later. For such a comparison, we plot LPR against the probability of change in the seats plurality party, as defined by Equation 6 .

$$
\Delta P P_{T}=\left(\sum_{t=1}^{T} I_{t}\right) / T, \text { where } I_{t}= \begin{cases}1 & \text { if } P P_{t} \neq P P_{t-1} \\ 0 & \text { otherwise }\end{cases}
$$

In particular, the probability of change in the plurality party, $\Delta P P_{T}$, is the number of times there was a change in the plurality party between the first recorded election and the election of interest, $T$, over the number of elections up to and including election $T$. We expect that plurality parties experience more competitive pressure in countries with a high $\triangle P P_{T}$; hence, if LPR is to reflect competitive pressure for plurality parties, it should have a positive relationship with the probability of change in the seats plurality party. Figure 3 confirms that LPR passes that test. ${ }^{16}$

[Figure 3 about here.]

A binary logit equation can offer a similar test, albeit with the advantage of predicting individual election losses of plurality status with the preceding loss probability. Applying this to the same data associates a unit change in loss probability with a 32-fold increase in the odds of a change in the plurality party in parliament. ${ }^{17}$

\section{Conclusion}

We propose and estimate what we believe to be the first cross-nationally valid measure of a key type of electoral competitiveness, electoral risk. Both measurement (e.g., Selway, 2011)

\footnotetext{
${ }^{16}$ Of course, pooled data like in Figure 3 do not necessarily mean that plurality party change is associated with higher loss probabilities in individual countries. We confirm that this is indeed the case in a figure in the Supporting Materials. In only one of the 22 sample countries - Greece - are loss probabilities lower when a plurality party changes due to an election.

$17 \frac{p r(\text { change }=1)}{p r(\text { change }=0)}=-2.011+3.45 L P R+\epsilon . \mathrm{N}=279$, s.e. $=.663, \mathrm{z}=5.21 ; e^{3.45}=31.567$
} 
and estimation methods (e.g., Rozenas, 2012) have notably improved in the study of politics in recent years. The measurement of electoral competitiveness, however, has lagged until recently, leaving scholars conducting cross-national research with a poor set of inadequate proxies. Unlike extant alternatives, our measure incorporates vote volatility, is specific to the largest party party in the legislature (not to the whole system), exogenous to most policy predictors, and designed to capture the perception and incentives of policy-makers. 


\section{References}

Adserà, Alícia, Carles Boix and Mark Payne. 2003. "Are You Being Served? Political Accountability and Quality of Government." Journal of Law, Economics, and Organization 19(2):445-90.

Alvarez, R Michael and Jonathan Nagler. 2004. "Party system compactness: Measurement and consequences." Political Analysis 12(1):46-62.

Ansolabehere, Stephen, James M. Snyder and Charles Stewart. 2001. "Candidate Positioning in U.S. House Elections." American Journal of Political Science 45(1):136-59.

Bartolini, Stefano and Peter Mair. 1990. Identity, Competition, and Electoral Availability: The Stabilisation of European Electorates 1885-1985. Cambridge, England and New York: Cambridge University Press.

Beck, Thorsten, George Clarke, Alberto Groff, Philip Keefer and Patrick Walsh. 2001. "New Tools in Comparative Political Economy: The Database of Political Institutions." The World Bank Economic Review 15(1):165-76.

Bischoff, Carina S. 2013. "Electorally unstable by supply or demand?an examination of the causes of electoral volatility in advanced industrial democracies." Public Choice 156(34):537-561.

Blais, Andre and Ignacio Lago. 2009. "A general measure of district competitiveness." Electoral Studies 28(1):94-100.

Bodet, Marc Andre. 2013. "Strongholds and Battlegrounds: Measuring Party Support Stability in Canada." Canadian Journal of Political Science 3(46):575-596.

Boyne, George A. 1998. "Party Competition and Local Spending Decisions." British Journal of Political Science 28(1):210-22. 
Brancati, Dawn. N.d. "Global Elections Database [computer file]." New York, NY: Global Elections Database [distributor], Date Accessed 2013. Website: http://www.globalelectionsdatabase.com.

Canes-Wrone, Brandice, David W. Brady and John F. Cogan. 2002. "Out of Step, Out of Office: Electoral Accountability and House Members' Voting." American Political Science Review 96(1):127-40.

Carey, John M and Simon Hix. 2011. "The Electoral Sweet Spot: Low-Magnitude Proportional Electoral Systems." American Journal of Political Science 55(2):383-397.

Chang, Eric CC, Mark A. Kayser, Drew Linzer and Ronald Rogowski. 2011. Electoral Systems and the Balance of Consumer-Producer Power. Cambridge University Press.

Chang, Eric C.C., Mark Andreas Kayser and Ronald Rogowski. 2008. "Electoral Systems and Real Prices: Panel Evidence for the OECD Countries, 1970-2000." British Journal of Political Science 38(4):739-51.

Chen, Jowei and Jonathan Rodden. 2013. "Unintentional Gerrymandering: Political Geography and Electoral Bias in Legislatures." Quarterly Journal of Political Science 8(3):239-69.

Döring, Holger and Philip Manow. 2012. "Parliament and government composition database (ParlGov): An infrastructure for empirical information on parties, elections and governments in modern democracies.". version 12/10-15 October 2012.

Elkins, David J. 1974. "The Measurement of Party Competition." American Political Science Review 68(2):682-700.

Grofman, Bernard and Peter Selb. 2009. "A Fully General Index of Political Competition." Electoral Studies 28(2):291-96.

Gugiu, Mihaiela Ristei and Miguel Centellas. 2013. "The Democracy Cluster Classification Index." Political Analysis 21(3):334-349. 
Hecock, R. Douglas. 2006. "Electoral Competition, Globalization, and Subnational Education Spending in Mexico, 1999-2004." American Journal of Political Science 50(4):950-61.

Hobolt, Sara B. and Robert Klemmensen. 2008. "Government Responsiveness and Political Competition in Comparative Perspective." Comparative Political Studies 41(3):309-37.

Hollyer, James R, B Peter Rosendorff and James Raymond Vreeland. 2014. "Measuring Transparency." Political Analysis p. mpu001.

Hopkin, Jonathan. 2008. Proportional Representation with Majoritarian Outcomes. In The politics of electoral systems, ed. Michael Gallagher and Paul Mitchell. Oxford and New York: Oxford University Press pp. 375-396.

Immergut, Ellen M. and Tarik Abou-Chadi. 2014. "How electoral vulnerability affects pension politics: Introducing a concept, measure and empirical application." European Journal of Political Research 53(2):269-287.

Jacobson, Gary. 1987. "The Marginals Never Vanished: Incumbency and Competition in Elections to the US House of Representatives, 1952-82." American Journal of Political Science 31(1):126-41.

Kayser, Mark Andreas and René Lindstädt. 2015. "Replication data for: A CrossNational Measure of Electoral Competitiveness." . http://dx.doi.org/10.7910/DVN/28591 UNF:5:WUwG4tgocRVYI7T1QYkt8g== Dataverse [Distributor] V1 [Version].

Koch, Jeffrey W. 1998. "Electoral Competitiveness and the Voting Decision: Evidence from the Pooled Senate Election Study." Political Behavior 20(4):295-311.

Kollman, Ken, Allen Hicken, Daniele Caramani and David Backer. N.d. "Constituency-Level Elections Archive (CLEA)." University of Michigan, Center for Political Studies [producer and distributor], Date Accessed 2013. Website: www.electiondataarchive.org. 
Lachat, Romain. 2011. "Electoral Competitiveness and Issue Voting." Political Behavior $33(4): 645-63$.

Linzer, Drew A. 2012a. "The Relationship between Seats and Votes in Multiparty Systems." Political Analysis 20(3):400-16.

Linzer, Drew A. 2012b. "Replication data for: The Relationship between Seats and Votes in Multiparty Systems." http://hdl.handle.net/1902.1/17691, IQSS Dataverse Network [Distributor] V1 [Version].

Linzer, Drew A. 2012c. "seatsvotes R package." Available here: http://dvn.iq.harvard.edu/dvn/faces/study/StudyPage.xhtml?studyId $=75023 \& t a b=f i l e s$.

Mann, Thomas E. 1978. Unsafe at any margin: Interpreting congressional elections. American Enterprise Institute for Public Policy Research Washington, DC.

Mayhew, David. 1974. "Congressional Elections: The Case of the Vanishing Marginals." Polity 6(3):295-317.

Monroe, Burt L. and Amanda G. Rose. 2002. "Electoral Systems and Unimagined Consequences: Partisan Effects of Districted Proportional Representation." American Journal of Political Science 46(1):67-89.

Orlowski, Matthias. 2014. "Linking votes to power. Measuring electoral competition at the party level." Paper presented at the Workshop, "Measuring Electoral and Political Competition and their Effects on Political Outcomes," 18 September 2014, Berlin .

Pemstein, Daniel, Stephen A Meserve and James Melton. 2010. "Democratic compromise: A latent variable analysis of ten measures of regime type." Political Analysis 18(4):426-449.

Powell, Bingham G. 1986. "American Voter Turnout in Comparative Perspective." American Political Science Review 80(1):17-43. 
Powell, Bingham G. 2000. Elections as Instruments of Democracy: Majoritarian and Proportional Visions. New Haven, CT: Yale University Press.

Przeworski, Adam and John Sprague. 1971. "Concepts in Search of Explicit Formulation: A Study in Measurement." Midwest Journal of Political Science 15(2):183-218.

Ranney, Austin. 1976. Parties in State Politics. In Politics in the American States: A Comparative Analysis, ed. Herbert Jacob and Kenneth Nelson Vines. Boston, MA: Little Brown.

Rogowski, Ronald and Mark A. Kayser. 2002. "Majoritarian Electoral Systems and Consumer Power: Price-Level Evidence from the OECD Countries." American Journal of Political Science 46(3):526-39.

Rozenas, Arturas. 2012. "A Statistical Model for Party-Systems Analysis." Political Analysis $20(2): 235-247$.

Sartori, Giovanni. 1976. Parties and Party Systems: A Framework for Analysis. New York, NY: Cambridge University Press.

Schleiter, Petra and Alisa M. Voznaya. 2012. "Party system Competitiveness and Corruption." Party Politics. doi: 10.1177/1354068812448690.

Selb, Peter. 2009. "A Deeper Look at the Proportionality-Turnout Nexus." Comparative Political Studies 42(4):527-48.

Selway, Joel Sawat. 2011. "The measurement of cross-cutting cleavages and other multidimensional cleavage structures." Political Analysis 19(1):48-65.

Sheather, Simon J. and Michael C. Jones. 1991. "A Reliable Data-based Bandwidth Selection Method for Kernel Density Estimation." Journal of the Royal Statistical Society, Series B (Methodological) 53(3):683-90. 
Silverman, Bernard W. 1986. Density Estimation for Statistics and Data Analysis. Boca Raton, FL: CRC Press.

Solé-Ollé, Albert. 2006. "The effects of party competition on Budget Outcomes: Empirical Evidence from Local Governments in Spain." Public Choice 126(1-2):145-76.

Tavits, Margit. 2005. "The Development of Stable Party Support: Electoral Dynamics in Post-Communist Europe." American Journal of Political Science 49(2):283-298. 


\begin{tabular}{l|rr|rr|c}
\hline \hline Country & Rank & Mean LPR & Rank & SD LPR & Electoral System \\
\hline Australia & 1 & .4965294 & 8 & .1893283 & SMD \\
Austria & 15 & .2041149 & 15 & .1607144 & $\mathrm{PR}$ \\
Belgium & 4 & .4030591 & 12 & .175925 & $\mathrm{PR}$ \\
Canada & 5 & .3603264 & 14 & .1613548 & SMD \\
Denmark & 19 & .0842332 & 18 & .1394477 & $\mathrm{PR}$ \\
Finland & 16 & .1795604 & 9 & .188086 & $\mathrm{PR}$ \\
France & 11 & .3116623 & 3 & .2577968 & $\mathrm{SMD}$ \\
Germany & 9 & .3229848 & 1 & .2726855 & $\mathrm{PR}$ \\
Greece & 10 & .3139305 & 13 & .1660727 & $\mathrm{PR}$ \\
Iceland & 18 & .1175663 & 22 & .1003214 & $\mathrm{PR}$ \\
Ireland & 20 & .079271 & 19 & .1284448 & $\mathrm{PR}$ \\
Italy & 17 & .1291531 & 16 & .1568425 & $\mathrm{PR}$ \\
Japan & 22 & .0683625 & 23 & .060517 & $\mathrm{PR}$ \\
Luxembourg & 14 & .2235547 & 17 & .1527407 & $\mathrm{PR}$ \\
Netherlands & 8 & .3258293 & 11 & .1827887 & $\mathrm{PR}$ \\
New Zealand & 2 & .4415718 & 6 & .1963949 & $\mathrm{SMD}$ \\
Norway & 21 & .0746939 & 21 & .1243041 & $\mathrm{PR}$ \\
Portugal & 7 & .3355697 & 10 & .1873746 & $\mathrm{PR}$ \\
Spain & 3 & .4263818 & 4 & .2354869 & $\mathrm{PR}$ \\
Sweden & 23 & .0463855 & 20 & .1268431 & $\mathrm{PR}$ \\
UK & 6 & .3401079 & 5 & .2273151 & SMD \\
USA & 12 & .2541187 & 7 & .1951658 & SMD \\
\hline \hline
\end{tabular}

Table 1: Means and standard deviations of plurality party loss probabilities, 1960-2011, by country. Time series for Japan and New Zealand stop at their electoral system changes in 1994 and 1996, respectively. 


\begin{tabular}{|c|c|c|c|c|c|c|}
\hline \multirow[b]{2}{*}{$L P R$} & \multicolumn{2}{|c|}{$\begin{array}{c}(1) \\
\text { Loss Probability }\end{array}$} & \multicolumn{2}{|c|}{$\begin{array}{c}(2) \\
\text { Vote Margin }\end{array}$} & \multicolumn{2}{|c|}{$\begin{array}{c}(3) \\
\text { Seat Margin }\end{array}$} \\
\hline & $-28.471^{* * *}$ & (6.630) & & & & \\
\hline$L P R^{2}$ & $31.421^{* *}$ & $(10.260)$ & & & & \\
\hline Vote Margin & & & 7.988 & $(6.825)$ & & \\
\hline Seat Margin & & & & & -3.741 & $(3.448)$ \\
\hline GDP per Capita & $0.001^{* * *}$ & $(0.000)$ & $0.001^{* * *}$ & $(0.000)$ & $0.001^{* * *}$ & $(0.000)$ \\
\hline Imports & $-0.311^{* * *}$ & $(0.039)$ & $-0.331^{* * *}$ & $(0.041)$ & $-0.342^{* * *}$ & $(0.041)$ \\
\hline InPopulation & $-1.039^{* *}$ & $(0.392)$ & $-1.427^{* * *}$ & $(0.384)$ & $-1.432^{* * *}$ & $(0.377)$ \\
\hline GDP Growth & $-1.133^{* * *}$ & $(0.192)$ & $-1.060^{* * *}$ & $(0.194)$ & $-1.026^{* * *}$ & $(0.192)$ \\
\hline$\Delta$ Exchange Rate & $-0.448^{* * *}$ & $(0.038)$ & $-0.479^{* * *}$ & $(0.041)$ & $-0.476^{* * *}$ & $(0.041)$ \\
\hline USA Inflation & $2.371^{* * *}$ & $(0.215)$ & $2.268^{* * *}$ & $(0.220)$ & $2.263^{* * *}$ & $(0.221)$ \\
\hline $1980 s$ & $-2.882^{*}$ & $(1.426)$ & $-4.720^{* *}$ & $(1.459)$ & $-4.610^{* *}$ & $(1.459)$ \\
\hline $1990 \mathrm{~s}$ & 1.421 & $(1.690)$ & 1.288 & $(1.747)$ & 1.376 & $(1.746)$ \\
\hline $2000 s$ & $-14.776^{* * *}$ & $(1.975)$ & $-16.435^{* * *}$ & $(2.056)$ & $-16.574^{* * *}$ & $(2.064)$ \\
\hline Constant & $101.352^{* * *}$ & $(7.651)$ & $102.969^{* * *}$ & $(7.852)$ & $104.580^{* * *}$ & $(7.711)$ \\
\hline$N$ & 833 & & 887 & & 887 & \\
\hline$R^{2}$ & 0.658 & & 0.652 & & 0.652 & \\
\hline Adj. $R^{2}$ & 0.653 & & 0.648 & & 0.648 & \\
\hline
\end{tabular}

Table 2: Real price levels and three measures of electoral competitiveness. Standard errors in parentheses. $p^{*}<.05 ; p^{* *}<.01 ; p^{* * *}<.01$. 


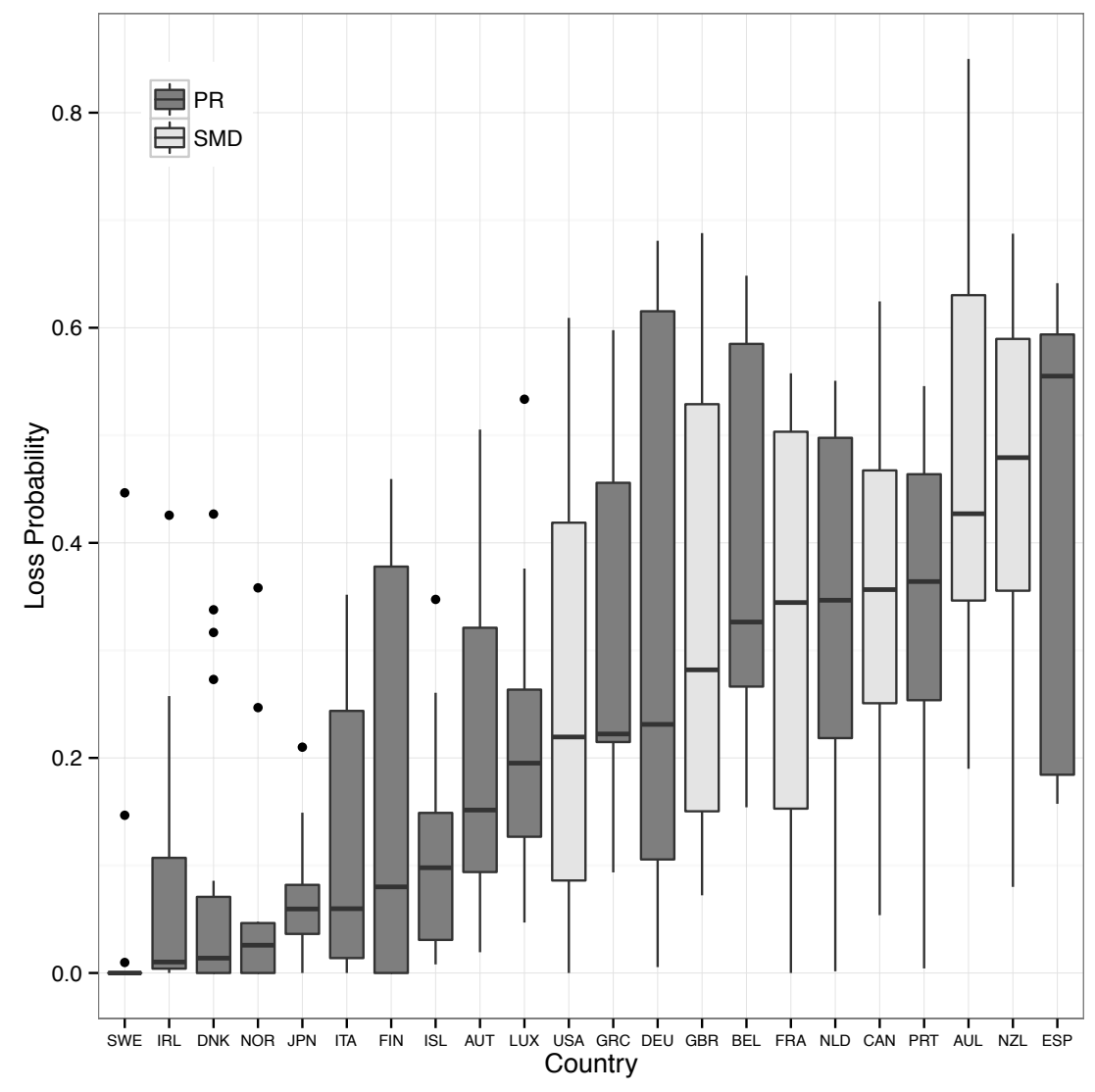

Figure 1: Box plots of plurality party loss probabilities. 

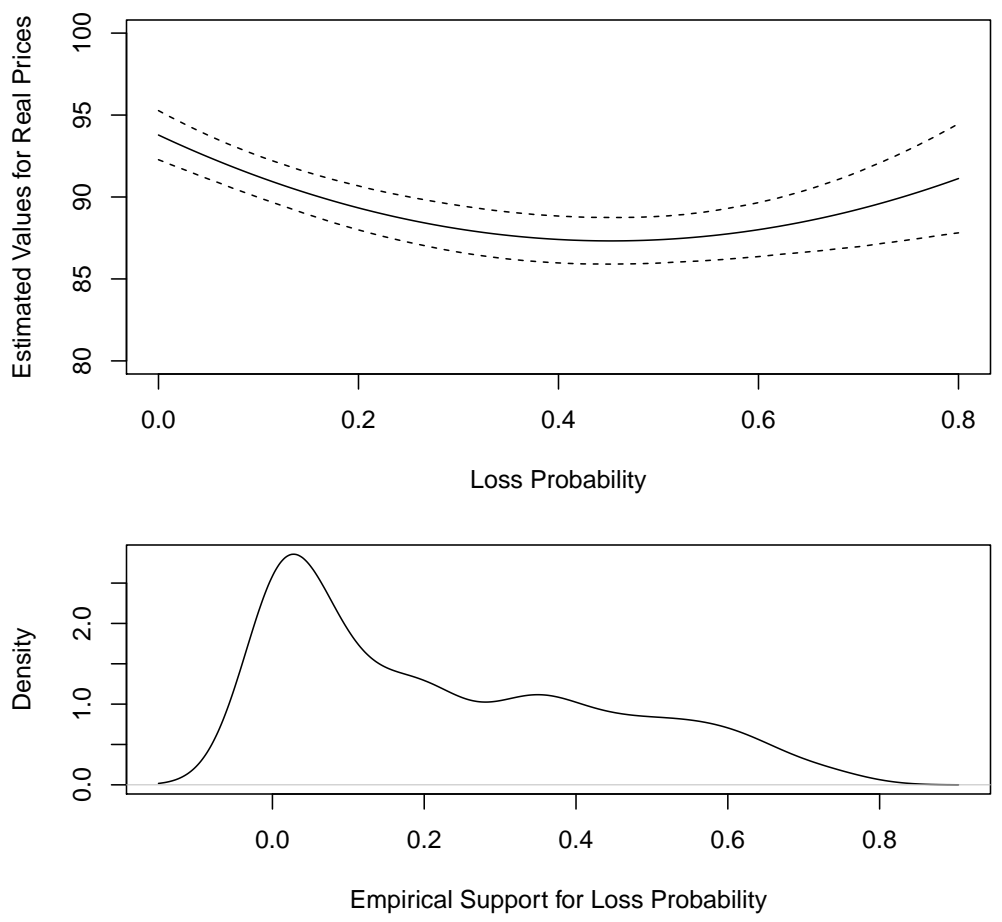

Figure 2: Predicted price levels for given loss probabilities. 


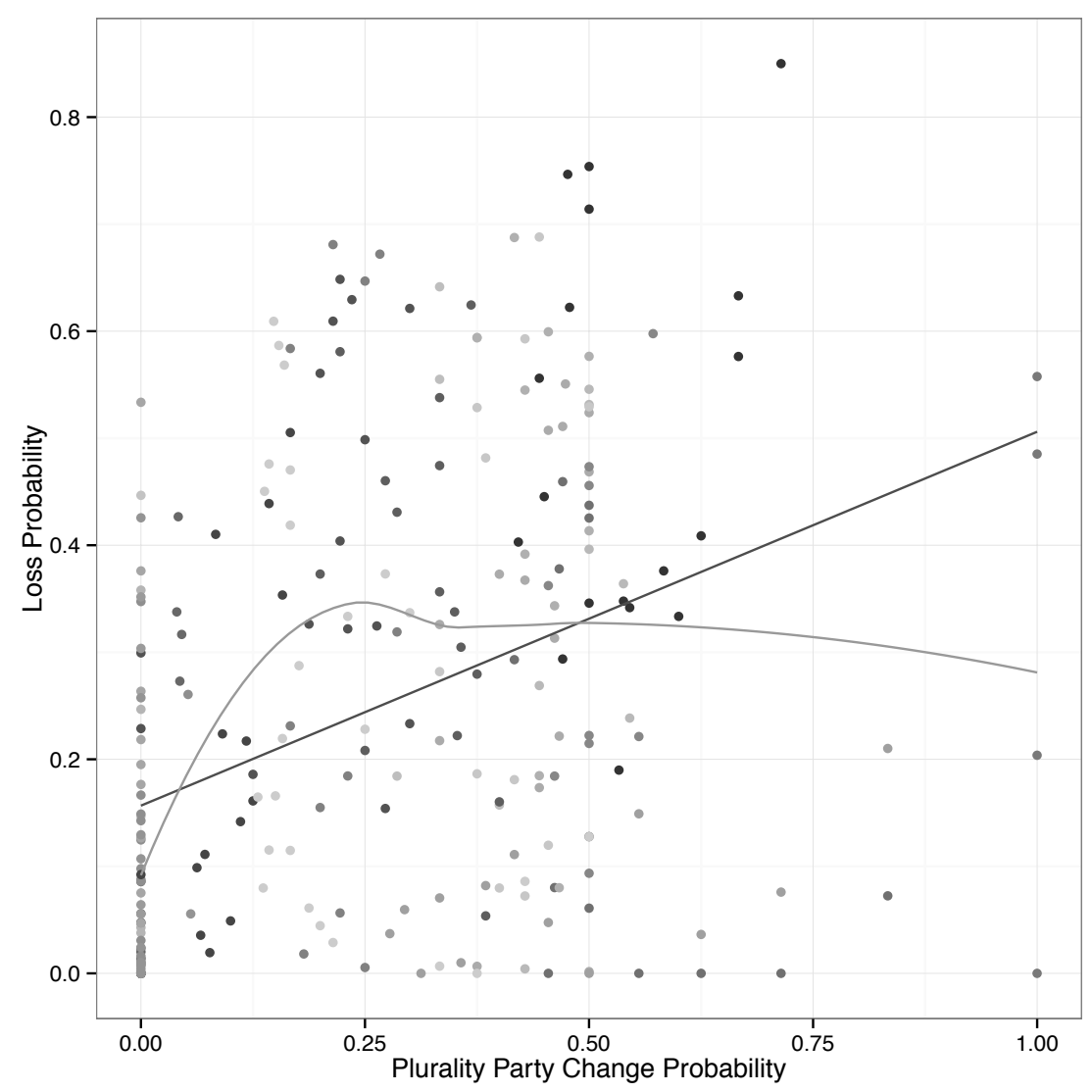

Figure 3: Loss probability (LPR) plotted against plurality party change probability, $\triangle P P_{T}$ (see Equation 6) with least-squares line and loess smoother. $N=26 \%$. OECD sample, 1960-2011. 